\title{
Manfaat Probiotik dalam Perawatan Kulit : Review
}

\author{
Elasari Dwi Pratiwi*, Susanti
}

Prodi Farmasi, Fakultas IImu Kesehatan, Universitas Muhammadiyah Lamongan, Jawa Timur, Indonesia ${ }^{\star}$ E-mail: susantipalarente@gmail.com

(Submit 12/9/2021, Revisi 11/10/2021, Diterima 19/10/2021, Terbit 3/11/2021)

\begin{abstract}
Abstrak
Probiotik sebagai mikroorganisme hidup dalam jumlah tertentu mampu memberikan manfaat kesehatan pada kulit. Penggunaan probiotik di beberapa negara Asia berkembang pesat, mulai dari penggunaan probiotik dalam industri pangan hingga industri kosmetik. Studi klinis terbaru melaporkan bahwa probiotik mampu mengobati eksim atopik, dermatitis atopik, menyembuhkan luka bakar, menghilangkan bekas luka, mengobati jerawat, mencegah penuaan dini, dan meregenerasi kulit. Review artikel ini bertujuan untuk membahas manfaat probiotik pada kulit sehingga dapat dikembangkan sebagai zat aktif pada produk kosmetik. Metode yang digunakan dalam penyusunan artikel yaitu study literatur berbagai jurnal internasioanal yang diakses dari situs Google Scholar dan ScienceDirect. Hasil review artikel menunjukkan probiotik yang paling banyak digunakan dalam produk kosmetik yaitu Enterococcus, Lactobacillus, dan Bifidobacterium. Probiotik memiliki aktivitas sebagai antibakteri, antijerawat, antioksidan, mencegah kerusakan kulit akibat radiasi UV, menurunkan sensitivitas kulit, mengurangi ketombe dan mampu menghasilkan asam hialuronat untuk meningkatkan kelembaban kulit dan mengurangi munculnya garis-garis halus dan kerutan. Dari review artikel ini dapat disimpulkan bahwa probiotik dapat digunakan sebagai ingredients pada produk kosmetik.
\end{abstract}

Kata kunci: Bioaktif, Kosmetik, Perawatan Kulit, Probiotik

\section{Pendahuluan}

World Health Organization (WHO) mendefinisikan probiotik sebagai mikroorganisme hidup dalam jumlah tertentu mampu memberikan manfaat kesehatan pada kulit. Probiotik merupakan kultur bakteri hidup yang akan mempengaruhi komposisi mikroorganisme lain di dalam tubuh. Probiotik dapat dicerna sebagai produk minuman fungsional untuk menjaga kesehatan usus kita. ${ }^{1}$ 
Penggunaan probiotik di beberapa negara Asia berkembang pesat, mulai dari penggunaan probiotik dalam industri pangan hingga industri kosmetik. Keberhasilan pangan probiotik berbasis susu fermentasi dan suplemen makanan di Pasar Korea Selatan telah berkembang pesat, khususnya yogurt probiotik yang dikonsumsi masyarakat Korea Selatan dalam lima dekade terakhir. ${ }^{2}$ Jepang mengembangkan minuman probiotik yang mengandung bakteri asam laktat untuk meningkatkan kesehatan usus, efek menurunkan adipositas perut, dan mengurangi peningkatan kadar asam urat serum. ${ }^{3}$ Sejak tahun 2016 produk probiotik pangan fermentasi telah menempati 10 besar tren makanan di China sehingga produk probiotik baru akan terus dikembangkan dan diperkenalkan di China. ${ }^{4}$ Peningkatan perhatian pada minuman fungsional yang mengandung probiotik di Thailand, karena menyebabkan intoleransi laktosa, kandungan kolesterol, dan alergi terhadap protein susu sehingga penelitian dan pengembangan minuman probiotik baru berbasis bahan baku non-susu akan terus dikembangkan. ${ }^{5}$

Pada umumnya probiotik telah mencapai penerimaan dan kesuksesan di Pasar Internasional. Kemajuan konsep dan teknis di bidang pangan fungsional telah mencapai puncak yang baik dan efektif sehingga perlu memperluas sifat fungsional yang diinginkan pada bidang yang lain juga. Penelitian lebih lanjut masih diperlukan untuk meningkatkan penggunaan probiotik dalam jalur molekuler yang mendasari fenotip kesehatan dan penyakit sebagai produk kosmetik. ${ }^{6}$ Beberapa penelitian dalam bidang kosmetik menyatakan bahwa probiotik memiliki kemampuan untuk meregenerasi kulit. Kulit sensitif memerlukan waktu yang lebih lama untuk meregenerasi kulit setelah kerusakan, tetapi probiotik mempercepat proses peremajaan kulit. ${ }^{1}$

Menurut Food and Drug Administration (FDA) kosmetik didefinisikan sebagai produk (tidak termasuk sabun) yang dimaksudkan untuk digunakan pada tubuh manusia untuk membersihkan, mempercantik, meningkatkan daya tarik atau mengubah penampilan ${ }^{7}$. Kulit merupakan jaringan terbesar dalam tubuh yang secara terus menerus mengalami regenerasi kulit yang dalam prosesnya melibatkan sel-sel mikroorganisme. Sebagian besar mikroorganisme yang ditemukan pada kulit bersifat aman bagi kulit karena memiliki sifat mutualisme dan memberikan banyak manfaat pada kesehatan kulit seperti mengeluarkan zat antibakteri, mencegah kolonisasi patogen, dan mempengaruhi respon imun. ${ }^{8,9}$

Studi klinis terbaru melaporkan bahwa probiotik mampu memberikan efek penyembuhan pada eksim atopik, dermatitis atopik, menyembuhkan luka bakar, menghilangkan bekas luka, mengobati jerawat, mencegah penuaan dini, dan meregenerasi kulit. ${ }^{10}$ Penggunaan probiotik dalam kosmetik masih perlu dilakukan penelitian, sedangkan permintaan untuk formulasi probiotik dalam kosmetik semakin meningkat. Oleh karena itu, review artikel ini bertujuan untuk memberikan informasi dan referensi mengenai manfaat probiotik dalam perawatan kulit. 


\section{Metode}

Metode pengumpulan data dan penulisan review artikel dimulai dengan melakukan penelusuran literatur berupa jurnal internasional dengan kata kunci "Probiotics benefits", "Probiotics Skincare", "Effect of Probiotics", "Functionality of Probiotics" dalam Google Scholar dan ScienceDirect. Jurnal-jurnal atau artikel penelitian yang diperoleh berada pada rentang tahun 2010-2021, kemudian poin penting pada beberapa jurnal tersebut dikaji ke dalam review artikel ini.

\section{Hasil}

Amerika Utara mengungkapkan bahwa setidaknya terdapat 50 produk dengan klaim mengandung probiotik. Produk kosmetik yang diproduksi bukan hanya ditujukan untuk perawatan kulit melainkan juga untuk deodoran dan perawatan rambut (Gambar 1).

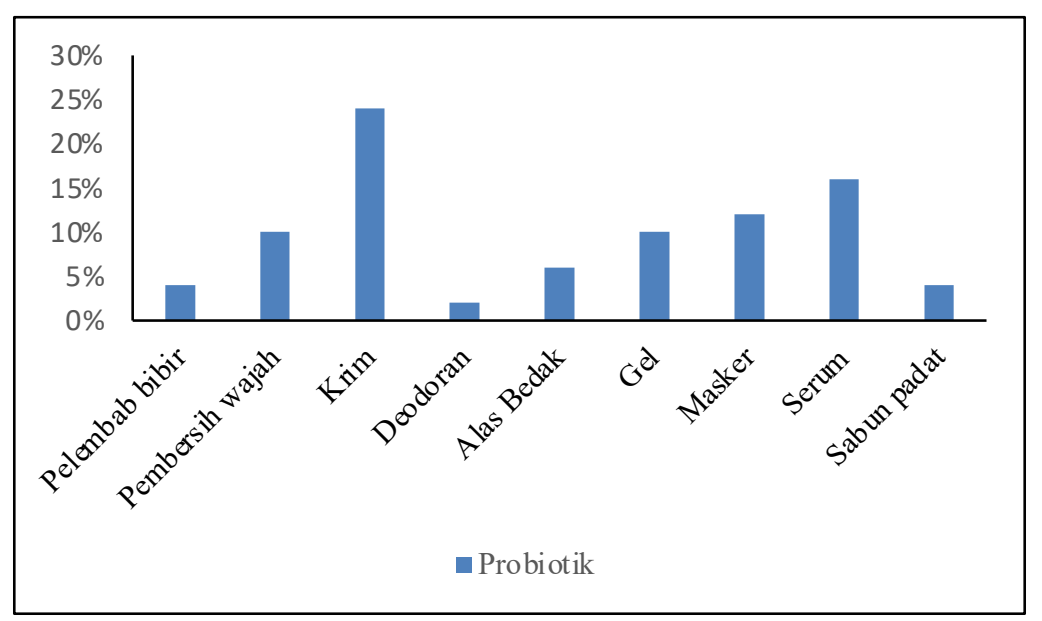

Gambar 1. Persentase probiotik yang digunakan dalam sediaan kosmetik di Amerika Utara

Adapun sifat-sifat probiotik yang bermanfaat dalam berbagai produk kosmetik dapat dilihat pada Tabel 1 di bawah ini.

Tabel 1. Sifat dan manfaat probiotik dalam produk kosmetik

\begin{tabular}{cccc}
\hline No. & Probiotik & Sifat Probiotik & Produk Kosmetik \\
\hline 1 & - & Lactobacillus & Antijerawat dan \\
& acidophilus & antibakteri & $\begin{array}{c}\text { Krim antijerawat dan } \\
\text { sabun cuci muka } \\
\text { antijerawat }\end{array}$ \\
& - Lactobacillus & & \\
& bulgaricus lysates & & \\
& - Lactobacillus & & \\
& plantarum & &
\end{tabular}


2

- Lactobacillus delbreuckii

- Lactobacillus casei lysates

$3 \quad$ Lactobacillus rhamnosus lysates

$4 \quad$ Streptococcus thermophilus

5 Bifidobacterium longum sp. Lysates

6

$$
\begin{aligned}
& \text { Lactobacillus } \\
& \text { paracasei }
\end{aligned}
$$

$7 \quad$ Streptococcus thermophilus
Antiinflamasi dan menenangkan

Mencegah kerusakan kulit akibat radiasi UV. Asam laktat sebagai agen pengelupasan dan pelembab yang sangat efektif

Menghidrasi kulit, memberikan efek antioksidan, dan kontrol $\mathrm{pH}$ Menurunkan
sensitivitas kulit

Bersifat antibakteri untuk mengurangi ketombe

$\begin{array}{cc}\text { Mampu } & \text { Krim pelembab; } \\ \text { menghasilkan asam } & \text { serum dan krim } \\ \text { hialuronat untuk } & \text { antikerut } \\ \text { meningkatkan } & \\ \text { kelembaban kulit dan } & \\ \text { mengurangi } & \\ \text { munculnya garis- } & \\ \text { garis halus dan } & \\ \text { kerutan } & \end{array}$

Krim pelembab; krim dan serum antiaging; krim anti keriput; krim mata

Gel dan serum pelembab kulit; sabun

Sampo antiketombe Sunscreen, scrub eksfoliasi, dan krim pelembab toner 


\section{Pembahasan}

\section{Mikroorganisme Kulit}

Kulit berfungsi untuk melindungi tubuh kita dari bahaya eksternal dengan bertindak sebagai penghalang fisik, pengaturan suhu tubuh, kontrol penguapan serta penyimpanan lipid dan air. Kulit terus-menerus mengalami pembaruan. Sebagian besar mikroorganisme yang ditemukan pada kulit adalah mikroorganisme yang tidak berbahaya bagi kulit, bahkan beberapa mikroorganisme dianggap memberikan manfaat kesehatan pada kulit dengan mengeluarkan respon antibakteri, mencegah kolonisasi bakteri patogen, dan mempengaruhi respon imun tubuh. ${ }^{11,12}$

Pada tahun 2001, Joshua Lederberg menggunakan istilah "mikrobioma" untuk menggambarkan mikroorganisme yang ada di seluruh tubuh. Ahli mikrobiologi dan dermatologi berupaya mengidentifikasi dan mendeskripsikan berbagai mikroorganisme yang ada di kulit manusia untuk memperkirakan jumlah setiap populasi memahami efek dermatologi yang diberikan oleh varietas mikroorganisme. ${ }^{13}$

Kulit kita dapat dipengaruhi oleh lingkungan, genetika, pola makan, dan gaya hidup. Oleh karena itu, kulit setiap manusia itu berbeda dan jenis mikroorganisme kulit setiap orang juga berbeda. Mikroorganisme kulit sangat tergantung pada lingkungan mikro dan fisiologi kulit. Kelenjar sebasea di dahi memiliki keragaman mikroorganisme terendah, mikroorganisme yang dominan adalah spesies Propionibacterium. Daerah yang lembab seperti ketiak, pusar, selangkangan memiliki keanekaragaman mikroorganisme dengan spesies Staphylococcus dan Corynebacterium sebagai mikroorganisme yang dominan. Kondisi asam yang dihasilkan dari degradasi sebum mampu menghambat patogen untuk menyerang dan membentuk kulit. Faktor lain yang memiliki efek langsung pada mikroorganisme kulit adalah kebersihan diri. Produk perawatan, seperti sabun, make up, dan produk perawatan kulit lainnya akan mengubah kondisi kulit dan mempengaruhi jenis mikroorganisme yang berada di kulit. ${ }^{14,15,13}$

Secara umum faktor yang mempengaruhi mikroorganisme pada kulit dapat dikategorikan menjadi dua, yaitu:

\section{Faktor Host}

Beberapa faktor yang termasuk dalam faktor host adalah usia, jenis kelamin, dan lokasi anatomi. Mikroorganisme kulit berbeda di antara berbagai kelompok umur, misalnya jenis bakteri yang berbeda secara signifikan antara kelompok usia muda dan lansia. Bayi baru lahir memperoleh bakteri yang menetap di kulit sejak dilahirkan dan komposisinya juga dipengaruhi oleh proses persalinan, misalnya bayi yang lahir melalui operasi Caesar didominasi oleh bakteri jenis Staphylococcus dan mikroorganisme lain yang berasal dari kulit ibu bayi tersebut. ${ }^{16,17,18}$ 
Perubahan komposisi lipid selama masa pubertas mendorong mikroorganisme lipofilik, seperti Propionibacterium acnes. Saat bakteri tersebut memperoleh energi dari metabolisme asam lemak di sebum, maka berbagai enzim disekresikan yang melukai lapisan jaringan kelenjar sebasea. Hubungannya dengan respon imun yang diaktifkan, ini menghasilkan kondisi kulit yang disebut acne vulgaris. Selain itu, usia remaja memiliki kelimpahan Staphylococcus aureus yang lebih tinggi, kemudian digantikan oleh bakteri lipofilik. Hal ini memiliki implikasi penting untuk gangguan kulit, seperti dermatitis atopik (atau eksim) yang paling umum pada masa remaja dan dewasa. ${ }^{15}$

\section{Faktor Lingkungan}

Kulit berfungsi sebagai perisai yang melindungi manusia terhadap efek berbahaya dari lingkungan. Ada interaksi yang seimbang antara mikroorganisme permanen dan mikroorganisme sementara pada kulit. Keseimbangan ini terus menerus tergantung pada faktor internal dan eksternal (termasuk lingkungan) yang mengubah komposisi mikroorganisme pada kulit. Perubahan keseimbangan ini ditandai dengan terjadinya dysbacteriosis yang dapat memperburuk penyakit kulit kronis seperti dermatitis atopik dan psoriasis atau jerawat. Pada dasarnya mikroorganisme kulit dipengaruhi oleh faktor-faktor, seperti suhu dan sinar ultraviolet. Mikroorganisme kulit juga dipengaruhi oleh gaya hidup, misalnya pecandu alkohol dan defisiensi vitamin menyebabkan keseimbangan mikroorganisme kulit sehingga menurunkan system imun terhadap infeksi. ${ }^{19,20}$

\section{Probiotik}

WHO mendefinisikan probiotik sebagai mikroorganisme hidup yang diberikan dalam jumlah tertentu mampu memberikan manfaat kesehatan. Probiotik adalah bakteri yang membantu menyeimbangkan bakteri "baik" dan "jahat" dalam tubuh untuk membantu memperkuat sistem imun. Probiotik merupakan kultur bakteri hidup apabila dioleskan akan mempengaruhi komposisi mikroorganisasi kulit. Probiotik dapat dicerna untuk menjaga kesehatan usus. Kesehatan usus juga dapat berdampak besar pada penampilan kulit sehingga penting untuk merawat kulit dari dalam ke luar secara topikal. Probiotik memiliki kemampuan untuk meregenerasi dan memperkuat kulit. Kulit sensitif mungkin memerlukan beberapa saat untuk memperbaiki dirinya sendiri setelah mengalami kerusakan. ${ }^{21}$

Menurut beberapa peneliti, probiotik yang dimasukkan ke dalam perawatan kulit sehingga membantu mempercepat proses peremajaan kulit. Beberapa perusahaan sudah memasukkan bakteri dan/atau ke dalam krim kulit dengan klaim "menyeimbangkan kembali" bakteri yang hidup dalam tubuh manusia dan menghasilkan kulit yang lebih sehat dan tampak lebih bercahaya. Meskipun sebagian orang sering menganggap bakteri dan mikroorganisme sebagai bakteri berbahaya, misalnya bakteri yang ada di usus membantu mencerna makanan, menghancurkan mikroorganisme penyebab penyakit, dan menghasilkan vitamin. Banyak mikroorganisme dalam produk probiotik memiliki karakteristik yang sama atau mirip dengan mikroorganisme alami yang hidup di dalam tubuh manusia. ${ }^{21}$ 
Beberapa tahun terakhir, banyak produk yang mengandung probiotik telah memasuki pasar, termasuk produk makanan yang difermentasi, suplemen makanan, produk farmasi yang disetujui, kosmetik, barang kebersihan, dan produk lainnya. Sampai saat ini, efek menguntungkan dari probiotik sebagian besar difokuskan pada sistem gastrointestinal. Namun, beberapa tahun terakhir ada laporan tentang potensi penggunaan probiotik pada produk perawatan kulit. ${ }^{22,10}$

Studi dan uji klinis telah dilakukan untuk menentukan efek probiotik dan mekanisme kerja dalam sistem gastrointestinal. Sebagian besar probiotik adalah bakteri laktat dari Lactobacillus dan Bifidobacterium. Pada kasus ketidakseimbangan mikroorganisme dikaitkan dengan peradangan kulit. Manfaat lain yang dilaporkan untuk kulit dari konsumsi probiotik adalah penyembuhan luka bakar dan bekas luka, meremajakan jaringan kulit, perlindungan terhadap sinar ultraviolet, dan meningkatkan kekebalan bawaan kulit. ${ }^{10}$

Beberapa probiotik yang paling banyak digunakan, yaitu:

1. Enterococcus, seperti E. faecium

2. Lactobacillus, seperti L. acidophilus, L. casei, L. paracasei

3. Bifidobacterium, seperti B. bifidum, B. longum, B. breve, B. infantis, B. remaja

Adapun fungsi probiotik dalam tubuh manusia, yaitu:

1. Menjaga keseimbangan makroorganisme normal (baik pencernaan dan kulit).

2. Menghasilkan asam rantai pendek-asetat, laktat, dan format yang berfungsi meningkatkan kesehatan usus besar.

3. Menurunkan kandungan nitrogen yang berpotensi berisiko dalam darah.

4. Menghasilkan faktor metabolism yang berfungsi menghambat aktivitas vital bakteri patogen yang mengurangi peradangan dan penyakit kulit.

Industri kosmetik yang mengembangkan produk perawatan kulit telah menentukan pentingnya probiotik sebagai "bahan bioaktif" untuk membantu meningkatkan kecantikan serta fungsi kulit. Produk-produk ini diaplikasikan secara topikal (body lotion, serum, sabun, dan lain-lain) dan produk yang dapat dicerna (minuman probiotik). ${ }^{23}$ Lactobacillus adalah bakteri yang paling umum yang dicantumkan dalam bahan bioaktif kosmetik serta metabolit bakteri, seperti asam laktat dan asam hialuronat terdaftar sebagai bahan produk kosmetik. Batas keamanan untuk mikroorganisme hidup dalam produk selain makanan biasanya sangat rendah, misalnya batas keamanan yang dapat diterima oleh FDA untuk mikroorganisme total (bukan patogen) dalam kosmetik adalah $500 \mathrm{cfu} / \mathrm{gram}$ dalam produk mata dan $1000 \mathrm{cfu} / \mathrm{g}$ untuk produk area lainnya. ${ }^{24}$

Formulasi kosmetik bersifat kompleks yang mengandung sejumlah bahan, termasuk pengawet untuk mencegah pertumbuhan mikroorganisme. Pengawet yang digunakan spektrum luas yang digabungkan dengan satu atau lebih senyawa dengan lebih selektif untuk memberikan efek antibakteri yang luas terhadap berbagai mikroorganisme yang berpotensi mencemari produk kosmetik. ${ }^{1}$ 
Beberapa industri kosmetik menggabungkan mikroorganisme baik untuk menambah kompleksitas pada formulasi dan proses pembuatan. Industri kosmetik mengatasi masalah ini dengan mengambil pendekatan alternatif untuk probiotik dengan menggunakan metabolit dari probiotik atau yang disebut dengan "bioaktif" yang dapat digunakan dalam produk kosmetik. Hal ini merupakan teknologi baru yang diambil dari penelitian tentang berbagai protein dan filtrat yang berbasis fermentasi untuk mempertahankan manfaat kecantikan tanpa kehadiran bakteri utuh atau hidup. ${ }^{1}$

Lactobacillus rhamnosus telah terbukti menghasilkan asam laktat sebagai satu-satunya produk metabolisme karbohidrat. Asam laktat pertama kali diproduksi di Amerika Serikat pada tahun 1883 oleh fermentasi bakteri asam laktat dari substrat gula. Bakteri asam laktat dari genus Lactobacillus telah digunakan dalam pembuatan asam laktat. Asam laktat digunakan sebagai agen pengelupasan dan pelembab yang sangat efektif. ${ }^{1}$ Penerapannya pada konsentrasi rendah (5\% v/v) menurunkan kohesi antar korneosit dan menginduksi pengelupasan kulit. ${ }^{25}$ Oleh karena itu, konsentrasi asam laktat yang berbeda menghasilkan hasil kosmetik yang berbeda pada epidermis dan dermis.

Para peneliti menciptakan produk kosmetik yang melembapkan kulit, menutrisi kulit, dan antiaging karena adanya asam laktat. Penggunaan produk ini meningkatkan daya tahan kulit terhadap faktor lingkungan dan memulihkan kondisi kulit lebih cepat setelah terpapar sinar ultraviolet. Beberapa perusahaan kosmetik juga memprakarsai produk perawatan rambut dengan probiotik sehingga memperkaya rambut dengan vitamin, membersihkan lebih efektif, dan mencukupi nutrisi rambut. ${ }^{1}$

Beberapa metabolit bakteri probiotik menunjukkan sifat antibakteri, khususnya Lactobacillus acidophilus menghasilkan Acidocin; Bifidobacterium sp. menghasilkan Bakteriosin N5; Lactobacillus casei menghasilkan Caseicin; Enterococcus faecium menghasilkan Enterocin dan Enterococcin; Lactobacillus plantarum menghasilkan Plantaricin dan Pediocin. Oleh karena itu, probiotik dapat membantu menghilangkan mikroorganisme patogen berbahaya yang melibatkan peradangan dan penyakit kulit. ${ }^{1}$

Perusahaan kosmetik mengembangkan krim, gel, sampo, dan produk perawatan kulit lainnya berdasarkan probiotik yang mengandung fragmen DNA bakteri dari bagian dinding selnya. Penelitian tersebut menandai adanya pengaruh positif kultur probiotik Lactobacillus delbreuckii, Lactobacillus rhamnosus, Lactobacillus salivarius, Lactobacillus paracasei, dan Bacillus subtilis dalam komposisi produk kosmetik untuk penyembuhan dermatitis atopik. ${ }^{1}$ 
Peningkatan produk yang mengandung probiotik di kalangan konsumen tidak serta merta menjadi keberhasilan dalam pengembangan ilmu dan produsen, hal ini dikarenakan masih banyaknya produk kosmetik yang tidak memenuhi karakteristik untuk sediaan yang mengandung probiotik. Formulasi kosmetik diproduksi berdasarkan bukti penelitian dan yang menarik bagi konsumen. Produk kosmetik yang mengandung probiotik, harus memenuhi 3 karakteristik yaitu strain harus dikarakterisasi termasuk secara genetik dan fenotip, produk harus mengandung mikroorganisme yang sesuai dengan literatur studi klinis sehingga memberikan manfaat pada target yang diinginkan, serta cara pemberian, dosis, dan lama penggunaan harus berdasarkan literatur studi klinis ${ }^{26}$.

Tabel 2. Produk Probiotik Kosmetik yang Beredar di Pasaran

\begin{tabular}{|c|c|c|c|}
\hline No. & Probiotik & Bentuk Sediaan & Merek Produk Kosmetik \\
\hline 1 & $\begin{array}{c}\text { Lactococcus ferment } \\
\text { lysate }\end{array}$ & Gel & $\begin{array}{c}\text { Biossance Squalane + } \\
\text { Probiotic Gel } \\
\text { Moisturizer }\end{array}$ \\
\hline 2 & $\begin{array}{l}\text { Bifida ferment lysate, } \\
\text { Lactobacillus, and } \\
\text { Streptococcus } \\
\text { thermophilus ferment }\end{array}$ & Serum & $\begin{array}{l}\text { Neogen Dermalogy } \\
\text { Probiotics Double } \\
\text { Action Serum }\end{array}$ \\
\hline 3 & $\begin{array}{c}\text { Lactococcus ferment } \\
\text { lysate }\end{array}$ & Facial Pads & $\begin{array}{c}\text { Elemis Dynamic } \\
\text { Resurfacing Facial } \\
\text { Pads }\end{array}$ \\
\hline 4 & Bifida ferment lysate & Essence & $\begin{array}{c}\text { Missha Time Revolution } \\
\text { The First Treatment } \\
\text { Essence Rx }\end{array}$ \\
\hline 5 & $\begin{array}{l}\text { actococcus ferment } \\
\text { lysate and live kefir } \\
\text { probiotics }\end{array}$ & Serum & $\begin{array}{l}\text { LaFlore Probiotic } \\
\text { Serum Concentrate }\end{array}$ \\
\hline 6 & $\begin{array}{c}\text { Lactococcus ferment } \\
\text { lysate }\end{array}$ & Serum & $\begin{array}{l}\text { Columbia Skincare } \\
\text { Probiotic Concentrate }\end{array}$ \\
\hline 7 & $\begin{array}{l}\text { Lactococcus ferment } \\
\text { Iysate; inactivated } \\
\text { strains of } \\
\text { Lactobacillus casei } \\
\text { and Lactobacillus } \\
\text { acidophilus }\end{array}$ & Masker & $\begin{array}{c}\text { Elizabeth Arden } \\
\text { Superstart Probiotic } \\
\text { Boost Skin Renewal } \\
\text { Biocellulose Mask }\end{array}$ \\
\hline
\end{tabular}

8 Lactococcus ferment

Cream Oil Glowbiotics HydraGlow lysate Cream Oil 


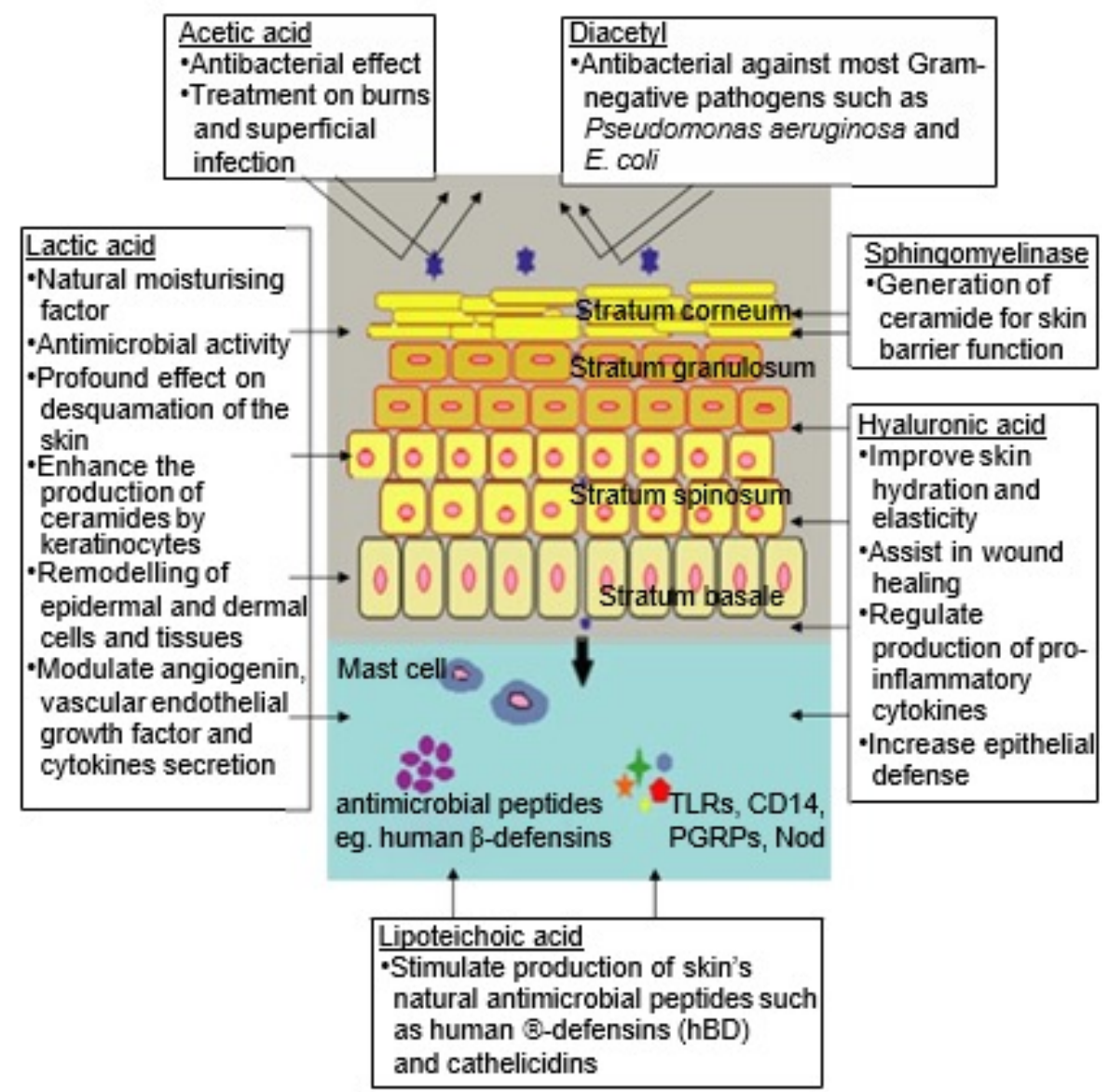

Gambar 2. Bioaktif dari Probiotik untuk aplikasi dermal

Bakteri asam laktat dapat menghasilkan peptida bioaktif yang dikenal sebagai bakteriosin yang memiliki aktivitas antibakteri terhadap bakteri patogen. Adanya molekul terlarut yang dihasilkan oleh bakteri laktat dengan potensi probiotik, ekspresi faktor virulensi bakteri oportunistik dapat ditekan. Temuan ini dapat mengarah pada pengobatan alternatif baru untuk infeksi bakteri meskipun mekanisme kerja yang tepat masih harus dipastikan. ${ }^{27}$ 
1. Asam Asetat

Asam asetat telah digunakan dalam pengobatan selama ribuan tahun. Beberapa penelitian membahas tentang aktivitas antibakteri asam asetat terhadap berbagai patogen. ${ }^{28}$ Literatur lain menyebutkan asam asetat digunakan sebagai sediaan topikal dalam penyembuhan infeksi luka bakar yang disebabkan oleh P.aeruginosa. ${ }^{29}$ Penelitian yang dilakukan oleh Hansson dan Faergemann menyatakan bahwa perawatan ulkus dengan menggunakan kasa yang mengandung asam asetat $0,25 \%$ menghasilkan jumlah rata-rata pada $S$. aureus berkurang secara signifikan $(p<0,05)$ dibandingkan dengan control. ${ }^{10}$ Aktivitas antibakteri asam asetat disebabkan oleh kemampuannya menurunkan $\mathrm{pH}$ sehingga pertumbuhan patogen tidak dapat hidup pada lingkungan tersebut. ${ }^{30}$ Namun, telah dilaporkan bahwa penggunaan asam lain seperti $\mathrm{HCl}$ pada $\mathrm{pH}$ yang sama tidak dapat menunjukkan efek antibakteri seperti asam asetat sehingga aktivitas antibakteri asam asetat dapat dihasilkan dari molekul asam asetat. ${ }^{30}$

\section{Diacetyl}

Diacetyl (2,3-Butanedione) merupakan senyawa organik yang ditemukan dalam makanan yang diproduksi selama proses fermentasi. ${ }^{31}$ Diacetyl diproduksi oleh beberapa spesies dari genus Leuconostoc, Streptococcus, Lactobacillus dan Pediococcus. Strain Lactobacilli dan Bifidobacteria dapat menghasilkan diacetyl dalam konsentrasi hingga $30 \mathrm{mg} / \mathrm{ml}^{-1}$ dan menunjukkan aktivitas sebagai antimikroorganisme pada aplikasi dermal dengan sensitivitas lebih besar terhadap bakteri gram negative dan jamur dibandingkan dengan bakteri gram positif. ${ }^{24,32}$ Penelitian oleh Lanciotti, 2003 menyatakan bahwa diacetyl memiliki aktivitas sebagai antimikroorganisme terhadap E. Coli dan S. aureus pada konsentrasi 100 $\mathrm{ppm}^{10}$. Penelitian tentang aktivitas anntimikroorganisme diacetyl sangat banyak ditemukan diberbagai jurnal, sedangkan penelitian tentang aplikasi diacetyl untuk perawatan kulit belum tersedia.

\section{Hyaluronic Acid}

Hyaluronic Acid (HA) adalah zat alami yang terdapat hampir disemua jaringan tubuh. Secara alami HA diklasifikasikan sebagai jenis molekul yang dikenal sebagai glycominoglycan (GAG). HA telah digunakan secara luas dalam bidang kedokteran seperti orthopedi dan kecantikan. ${ }^{33}$ Akhir-akhir ini, beberapa penelitian mengungkapkan bahwa manfaat HA sebagai ingredients dalam perawatan kulit sangat menjanjikan, seperti menyamarkan penampilan kulit, melembabkan, dan membuat kulit tampak lebih muda. ${ }^{34}$ 


\section{Lactic Acid}

Lactic acid, dikategorikan sebagai salah satu asam $\alpha$-hydroxy acids (AHAs) merupakan asam organik dengan satu gugus hidroksil yang terikat pada posisi alfa. Lactic acid dapat diproduksi baik oleh fermentasi mikroorganisme maupun sintesis kimia. ${ }^{10}$ Lactic acid memiliki banyak manfaat terhadap perawatan kulit seperti sebagai moisturizer, hand and body lotion, dan micro peeling. ${ }^{35}$ Selain itu, Lactic acid juga digunakan sebagai exfoliator dan chemical peeling agent karena efeknya yang sangat besar pada desquamation kulit serta memiliki kemampuan dalam meningkatkan fungsi penghalang stratum korneum dan meningkatkan produksi ceramide oleh keratinosit.

\section{Lipotheicoic Acid}

Lipoteichoic acid (LTA) merupakan komponen structural dari dinding sel yang ditemukan pada bakteri gram positif dan memainkan peran penting dalam pertumbuhan dan fisiologi bakteri. ${ }^{36}$ LTA yang berasal dari S. aureus dapat secara sinergis menginduksi dan melepaskan factor pertumbuhan hepatosi dan fibroblast kulit manusia oleh interleukin 1 alfa dan beta. ${ }^{37}$ Selaim memiliki aktivitas sebagai antimikroorganisme, LTA melalui human $\beta$-defensins (hBD) juga berkontribusi dalam penyembuhan luka dan sebagai imunomodulator. ${ }^{38}$

\section{Sphingomyelinase}

Sphingomyelinase (SMase) merupakan enzim yang menghasilkan generasi family ceramides dan phosphorylcholine. SMase terletak pada lapisan epidermis bagian luar dan memiliki fungsi sebagai pengalang kulit. ${ }^{39,40}$ SMase diklasifikasikan menjadi asam, basa dan netral berdasarkan pH optimalnya. Penelitian oleh Lew, et all tahun 2012 menyatakan bahwa strain lactobacilli dan bifidobacterial pada konsentrasi yang cukup dapat memproduksi baik asam dan netral SMase dengan tujuan meningkatkan produksi ceramides dalam sel kulit sehingga mampu meningkatkan sifat penghalang kulit. ${ }^{10}$

\section{Penghantaran Sediaan Topikal Probiotik}

Pada dasarnya perawatan kulit menggunakan dapat menggunakan rute oral dan topikal. Probiotik yang diberikan secara oral telah terbukti mempengaruhi mikrobioma usus yang mengarah pada perbaikan potensial pada kondisi kulit seperti dermatitis, atopik, dan jerawat.41 Sediaan topikal yang mengandung probiotik merupakan tantangan bagi industri farmasi kosmetik, ini dikarenakan formula yang diciptakan harus dapat mempertahankan viabilitas bakteri probiotik dari awal produksi hingga terdistribusi ke tangan konsumen. Formulasi probiotik lebih baik menggunakan basis minyak daripada basis air, namun perlu diperhatikan kembali terkait seberapa mudah organisme dapat bertahan pada basis minyak setelah di aplikasikan pada kulit dan kemudian menjadi cukup aktif secara metabolik untuk memberikan efek probiotik yang diinginkan. Sifat antibakteri dan imunomodilator dari probiotik menjadikannya kandidat yang menjanjikan untuk penyakit kulit seperti jerawat, dermatitis atopik dan membantu proses penyembuhan luka. 42 


\section{Formulasi Kosmetik Probiotik}

Mikroenkapsulasi telah digunakan dalam formula topikal untuk memperpanjang umur simpan dan viabilitas probiotik. Industri kosmetik harus menciptakan formula topikal yang mempertahankan viabilitas bakteri probiotik dari produksi sampai ke konsumen. Produk krim tidak diproduksi dalam kondisi steril sehingga pengawet sering ditambahkan karena sifat bakterisida dan/atau bakteriostatik. Hal ini berpotensi untuk mempengaruhi kelangsungan hidup strain probiotik. Produk kosmetik diharapkan memiliki kandungan mikroorganisme yang rendah, yaitu $<500 \mathrm{CFU} / \mathrm{g}$ untuk produk area mata dan $<1000 \mathrm{CFU} / \mathrm{g}$ untuk produk lainnya. ${ }^{43}$

Dalam membuat sebuah produk kosmetik, sebaiknya memperhatikan eksipien yang digunakan sehingga menghasilkan produk yang berkualitas dan memiliki mutu yang baik. Eksipien yang digunakan dalam produk probiotik sama halnya dengan eksipien yang umum digunakan dalam sediaan kosmetik, seperti mineral oil, tween 80 dan span 80 , propilen glikol, xanthan gum, metil paraben, propil paraben, dan trietanolamin ${ }^{44}$.

\section{Simpulan}

Berdasarkan hasil review artikel, probiotik memiliki banyak manfaat pada kesehatan tubuh manusia baik pada saluran pencernaan (usus) maupun pada kesehatan kulit. Bioaktif dari probiotik dapat digunakan sebagai ingredients dalam perawatan kulit yang sangat menjanjikan, seperti menyamarkan penampilan kulit, melembabkan, dan membuat kulit tampak lebih muda. Penggunaan probiotik akan terus berkembang dalam produk kosmetik dilihat dari manfaat probiotik terhadap kesehatan kulit serta trand industri farmasi yang mulai menggunakan probiotik.

\section{Daftar Pustaka}

1. Nisha K. Kurzekar DW. "Probiotics" In Skin Care Product - A Review. Published online 2018.

2. Lim K, Koh J. Chapter 5 - Fermented foods and probiotic beverages in Korea. In: Panda SK, Kellershohn J, Russell IBT-PB, eds. Academic Press; 2021:61-80. doi:https://doi.org/10.1016/B978-0-12-818588-9.00016-4

3. Sugahara H, Hirota T. Chapter 3 - Probiotic beverages in Japan (some history and current developments). In: Panda SK, Kellershohn J, Russell IBT-PB, eds. Academic Press; 2021:35-48. doi:https://doi.org/10.1016/B978-0-12-818588-9.00005-X

4. Chen W. Chapter 4 - Probiotic beverages in China. In: Panda SK, Kellershohn J, Russell IBT-PB, eds. Academic Press; 2021:49-60. doi:https://doi.org/10.1016/B9780-12-818588-9.00003-6

5. Trevanich S. Chapter 6 - Probiotic beverages in Thailand: Health attributes and future trends. In: Panda SK, Kellershohn J, Russell IBT-PB, eds. Academic Press; 2021:81-97. doi:https://doi.org/10.1016/B978-0-12-818588-9.00007-3

6. Paramithiotis S, Syrokou MK, Drosinos EH. Chapter 21 - Thoughts on the future of probiotic beverages. In: Panda SK, Kellershohn J, Russell IBT-PB, eds. Academic Press; 2021:441-466. doi:https://doi.org/10.1016/B978-0-12-818588-9.00022-X 
7. Cosmetics Overview. In: Us Food and Drug Administration. ; 2021. https://www.fda.gov/industry/regulated-products/cosmetics-overview\#cosmetic

8. Gao Z, Tseng CH, Strober BE, Pei Z, Blaser MJ. Substantial alterations of the cutaneous bacterial biota in psoriatic lesions. PLoS One. 2008;3(7). doi:10.1371/journal.pone.0002719

9. Dunn AB, Hanson L, Vandevusse L, Leslie S. Through the Microbial Looking Glass: Premature Labor, Preeclampsia, and Gestational Diabetes: A Scoping Review. J Perinat Neonatal Nurs. 2019;33(1):35-51. doi:10.1097/JPN.0000000000000375

10. Lew LC, Liong MT. Bioactives from probiotics for dermal health: Functions and benefits. J Appl Microbiol. 2013;114(5):1241-1253. doi:10.1111/jam.12137

11. Dréno $B$, Araviiskaia $E$, Berardesca $E$, et al. Microbiome in healthy skin, update for dermatologists. J Eur Acad Dermatol Venereol. 2016;30(12):2038-2047. doi:10.1111/jdv.13965

12. Byrd AL, Belkaid Y, Segre JA. The human skin microbiome. Nat Rev Microbiol. 2018;16(3):143-155. doi:10.1038/nrmicro.2017.157

13. Schommer NN GR. Structure and function of the human skin microbiome. Trends Microbiol. 2013;21(21):660-668. doi:10.1016/j.tim.2013.10.001

14. Fitz-Gibbon S, Tomida S, Chiu BH, et al. Propionibacterium acnes strain populations in the human skin microbiome associated with acne. J Invest Dermatol. 2013;133(9):2152-2160. doi:10.1038/jid.2013.21

15. Oh J, Conlan S, Polley EC, Segre JA, Kong HH. Shifts in human skin and nares microbiota of healthy children and adults. Genome Med. 2012;4(10):77. doi:10.1186/gm378

16. Cho I, Blaser MJ. The human microbiome: At the interface of health and disease. Nat Rev Genet. 2012;13(4):260-270. doi:10.1038/nrg3182

17. Kong H. Eczema, Immunity and the Skin Microbiome. Published online 2013:1-38. http://www.genome.gov/Multimedia/Slides/HumanMicrobiomeScience2013/21_Kong .pdf\%5Cnpapers3://publication/uuid/AB6FDFCF-B67D-4AC0-8631-93245BD67B87

18. Prescott SL, Larcombe DL, Logan AC, et al. The skin microbiome: Impact of modern environments on skin ecology, barrier integrity, and systemic immune programming. World Allergy Organ J. 2017;10(1):1-16. doi:10.1186/s40413-017-0160-5

19. Findley K, Oh J, Yang J, et al. Topographic diversity of fungal and bacterial communities in human skin. Nature. 2013;498(7454):367-370. doi:10.1038/nature12171

20. Gioti, A., Nystedt, B., Li, W., Xu, J., Andersson, A., Averette AF. Genomic Insights into the Atopic Eczema-Associated Skin Commensal Yeast Malassezia sympodialis. MBio. 2013;11(3). doi:10.1128/mBio.00572-12

21. Lopes EG, Moreira DA, Gullón P, Gullón B, Cardelle-Cobas A, Tavaria FK. Topical application of probiotics in skin: adhesion, antimicrobial and antibiofilm in vitro assays. J Appl Microbiol. 2017;122(2):450-461. doi:10.1111/jam.13349

22. Krutmann J. Pre- and Probiotics for Human Skin. Clin Plast Surg. 2012;39(1):59-64. doi:10.1016/j.cps.2011.09.009

23. Foligné $B$, Daniel $C$, Pot $B$. Probiotics from research to market: the possibilities, risks and challenges. Curr Opin Microbiol. 2013;16(3):284-292. doi:https://doi.org/10.1016/j.mib.2013.06.008 
24. Lew LC, Gan CY, Liong MT. Dermal bioactives from lactobacilli and bifidobacteria. Ann Microbiol. 2013;63(3):1047-1055. doi:10.1007/s13213-012-0561-1

25. Babilas $P$, Knie U, Abels $C$. Kosmetische und dermatologische Anwendung von Alpha-Hydroxysäuren. JDDG - J Ger Soc Dermatology. 2012;10(7):488-491. doi:10.1111/j.1610-0387.2012.07939.x

26. Puebla-Barragan S, Reid G. Probiotics in cosmetic and personal care products: Trends and challenges. Molecules. 2021;26(5):1-11. doi:10.3390/molecules26051249

27. Shi LH, Balakrishnan K, Thiagarajah K, Mohd Ismail NI, Yin OS. Beneficial properties of probiotics. Trop Life Sci Res. 2016;27(2):73-90. doi:10.21315/tlsr2016.27.2.6

28. Cortesia $C$, Vilchèze $C$, Bernut $A$, et al. Acetic acid, the active component of vinegar, is an effective tuberculocidal disinfectant. MBio. 2014;5(2). doi:10.1128/mBio.0001314

29. Nagoba BS, Selkar SP, Wadher BJ, Gandhi RC. Acetic acid treatment of pseudomonal wound infections - A review. J Infect Public Health. 2013;6(6):410-415. doi:10.1016/j.jiph.2013.05.005

30. Bjarnsholt T, Alhede M, Jensen P $\varnothing$, et al. Antibiofilm Properties of Acetic Acid. Adv Wound Care. 2015;4(7):363-372. doi:10.1089/wound.2014.0554

31.Zandi M, Mohebbi M, Varidi M, Ramezanian N. Evaluation of diacetyl encapsulated alginate-whey protein microspheres release kinetics and mechanism at simulated mouth conditions. Food Res Int. 2014;56:211-217. doi:10.1016/j.foodres.2013.11.035

32. Lew LC, Choi SB, Khoo BY, Liong MT. Mn2+ and Mg2+ improved sphingomyelinase production by Lactobacillus rhamnosus FTDC 8313 and binding affinity to sphingomyelin for generation of ceramides. Process Biochem. 2013;48(12):18151821. doi:10.1016/j.procbio.2013.09.023

33. Neuman MG, Nanau RM, Oruña-Sanchez L, Coto G. Hyaluronic acid and wound healing. J Pharm Pharm Sci. 2015;18(1):53-60. doi:10.18433/j3k89d

34. Narurkar VA, Fabi SG, Bucay VW, Tedaldi R, Downie JB, Zeichner JA, Butterwick K, Taub A, Kadoya K, Makino ET, Mehta RC VV. Rejuvenating Hydrator: Restoring Epidermal Hyaluronic Acid Homeostasis With Instant Benefits. J Drugs Dermatol. 2016;1(2):24-37.

35. Alsaheb RAA, Aladdin A, Othman NZ, et al. Lactic acid applications in pharmaceutical and cosmeceutical industries. J Chem Pharm Res. 2015;7(10):729735.

36. Matthew G. Percy and Angelika Gründling. Lipoteichoic Acid Synthesis and Function in Gram-Positive Bacteria. Annu Rev Microbiol. 2014;68:81-100.

37. Sugiyama A, Arakaki R, Ohnishi T, Arakaki N, Daikuhara Y, Takada H. Lipoteichoic acid and interleukin 1 stimulate synergistically production of hepatocyte growth factor (scatter factor) in human gingival fibroblasts in culture. Infect Immun. 1996;64(4):1426-1431. doi:10.1128/iai.64.4.1426-1431.1996

38. Niyonsaba F. Protective roles of the skin against infection: Implication of naturally occurring human antimicrobial agents $\beta$-defensins, cathelicidin LL-37 and lysozyme. J Dermatol Sci. 2005;40(3):157-168. 
39. Jensen, J.M., Forl, M., Winoto-Morbach, S., Seite, S. S, M., Proksch, E. and Schutze S. Acid and neutral sphingomyelinase, ceramide synthase, and acid ceramidase activities in cutaneous aging. Exp Dermatol. 2005;14(609-618).

40. Jensen, J.M., Folster-Holst, R., Baranowsky, A., Schunck M, Winoto-Morbach, S., Neumann, C., Schutze S and, Proksch E. Impaired sphingomyelinase activity and epidermal differentiation in atopic dermatitis. J Invest Dermatol. 2004;122:14231431.

41. Jung GW, Tse JE, Guiha I, Rao J. Prospective, randomized, open-label trial comparing the safety, efficacy, and tolerability of an acne treatment regimen with and without a probiotic supplement and minocycline in subjects with mild to moderate acne. J Cutan Med Surg. 2013;17(2):114-122. doi:10.2310/7750.2012.12026

42. Reid G, Abrahamsson T, Bailey $M$, et al. How do probiotics and prebiotics function at distant sites? Benef Microbes. 2017;8(4):521-533. doi:10.3920/BM2016.0222

43. Puebla-Barragan S, Reid G. Forty-five-year evolution of probiotic therapy. Microb Cell. 2019;6(4):184-196. doi:10.15698/mic2019.04.673

44. Al-Saedi F, Dakhil IA, Hummod A, Nather Q. Formulation and evaluation of acetic acid lotion for the treatment of wound infection. Indian J Public Heal Res Dev. 2019;10(11):4827-4832. doi:10.5958/0976-5506.2019.03914.7 